\title{
Tertiary interactions determine the accuracy of RNA folding
}

\author{
Seema Chauhan ${ }^{1}$ and Sarah A. Woodson ${ }^{2}$ \\ 1Department of Chemistry, Johns Hopkins University, 3400 N. Charles St., Baltimore, MD 21218 USA \\ 2T.C. Jenkins Department of Biophysics, Johns Hopkins University, 3400 N. Charles St., Baltimore, MD \\ 21218 USA
}

\begin{abstract}
RNAs must fold into unique three-dimensional structures to function in the cell, but how each polynucleotide finds its native structure is not understood. To investigate whether the stability of the tertiary structure determines the speed and accuracy of RNA folding, docking of a tetraloop with its receptor in a bacterial group I ribozyme was perturbed by site-directed mutagenesis. Disruption of the tetraloop or its receptor destabilizes tertiary interactions throughout the ribozyme by $2-3 \mathrm{kcal} /$ mol, demonstrating that tertiary interactions form cooperatively in the transition from a native-like intermediate to the native state. Nondenaturing PAGE and RNase T1 digestion showed that base pairs form less homogeneously in the mutant RNAs during the transition from the unfolded state to the intermediate. Thus, tertiary interactions between helices bias the ensemble of secondary structures toward native-like conformations. Time-resolved hydroxyl radical footprinting showed that the wild type ribozyme folds completely within 5-20 ms. By contrast, only 40-60\% of a tetraloop mutant ribozyme folds in $30-40 \mathrm{~ms}$, with the remainder folding in $30-200 \mathrm{~s}$ via non-native intermediates. Therefore, destabilization of tetraloop-receptor docking introduces an alternate folding pathway in the otherwise smooth energy landscape of the wild type ribozyme. Our results show that stable tertiary structure increases the flux through folding pathways that lead directly and rapidly to the native structure.
\end{abstract}

\section{Keywords}

ribozyme; group I intron; footprinting; tetraloop; cooperative folding

\section{Introduction}

The self-assembly of biological macromolecules into a unique three-dimensional structure relies on the cooperation of many weak interactions. The cooperativity of these interactions determines the folding free energy landscape and the trajectory of the folding reaction. ${ }^{1,2}$ RNA folding landscapes are often rough, because RNA secondary structures are stable and form independently of weaker tertiary interactions. ${ }^{3,4}$ Consequently, RNA molecules frequently become trapped in metastable, misfolded structures in vitro. 5,6 Understanding how RNAs avoid misfolding is crucial, because incorrectly folded RNAs may aggregate or be prematurely degraded in the cell. In this paper, we report that the cooperativity of folding and the avoidance of misfolded intermediates in a bacterial ribozyme depend on the stability of the tertiary structure, rather than the base pairing potential.

Contact information: tel: (410) 516-2015 FAX: (410) 516-4118 email: swoodson@jhu.edu; chauhan@jhu.edu

Supporting Information Available

Additional Figures (S1-S6) and Tables (S1-S2). This material is available free of charge on the Internet at http://pubs.acs.org 
The stabilities of RNA double helices can be predicted from empirical free energy parameters that account for the cooperativity of neighboring base pairs. ${ }^{7}$ By contrast, less is known about the thermodynamics of RNA tertiary interactions, and whether they cooperatively stabilize the native structure. In one study, adjacent hydrogen bonds in a "ribose zipper" motif added noncooperatively to the stability of the P4-P6 domain of Tetrahymena ribozyme. ${ }^{8}$ However, hydrogen bonds in small loops and pseudoknots form cooperative networks. ${ }^{9}$ Similarly, urea denaturation experiments suggested that at least three interdomain tertiary contacts in Tetrahymena ribozyme are energetically coupled to one another. ${ }^{10}$

In this study we examine the tertiary folding of a 195-nucleotide ribozyme derived from a selfsplicing group I intron in Azoarcus pre-tRNA ${ }^{\text {Ile }} 11$ The Azoarcus ribozyme folds hierarchically, in that the core helices assemble in $\sim 0.2 \mathrm{mM} \mathrm{Mg}^{2+}$, while stable tertiary structure and catalytic activity appear in $\sim 2 \mathrm{mM} \mathrm{Mg}^{2+} .12,13$ Helix assembly correlates with global compaction of the RNA from the unfolded state $\left(\mathrm{U} ; \mathrm{R}_{\mathrm{g}}=65 \pm 3 \AA\right.$ ) to an ensemble of compact intermediates $\left(\mathrm{I}_{\mathrm{c}} ; \mathrm{R}_{\mathrm{g}}=30.9 \pm 0.5 \AA\right.$ ) which have dimensions similar to the native state $(\mathrm{N}) \cdot 13,14$

There are several indications that the $\mathrm{I}_{\mathrm{C}}$ intermediate has a native-like topology and contains some tertiary structure. First, $\mathrm{R}_{\mathrm{g}}$ does not decrease significantly from $\mathrm{I}_{\mathrm{c}}$ to N. ${ }^{13}$ Second, smallangle $\mathrm{X}$-ray scattering studies showed that tertiary interactions between helices help stabilize $\mathrm{I}_{\mathrm{C}}$, even though the RNA backbone is accessible to bulk solvent in $\mathrm{I}_{\mathrm{C}}{ }^{14}$ Third, unlike many multidomain RNAs, $80-90 \%$ of the Azoarcus ribozyme folds in less than $50 \mathrm{~ms}$ in $15 \mathrm{mM}$ $\mathrm{MgCl}_{2} .{ }^{12}$ The rapid and concerted formation of the native tertiary structure suggests most of the Azoarcus ribozyme folds through native-like intermediates, without becoming kinetically trapped in metastable structures.

To investigate the cooperativity of tertiary interactions in the Azoarcus ribozyme, we used sitedirected mutagenesis to perturb a tetraloop-receptor interaction that bridges two major helical domains. We previously found that a mutation in the GAAA tetraloop of P9 (A190 to U), which disrupts docking with its receptor in $\mathrm{J} 5 / 5 \mathrm{a}$, globally destabilizes both the intermediate $\left(\mathrm{I}_{\mathrm{C}}\right)$ and native states in Azoarcus ribozyme. ${ }^{14}$ Here, we compare local tertiary folding transitions in the wild type and mutant RNAs using hydroxyl radical footprinting, which reports the average solvent accessibility of ribose $\mathrm{C}^{\prime}$ ' and $\mathrm{C}^{\prime}$ ' atoms at individual nucleotides.

We find that the disruption of tetraloop-receptor docking affects the formation of all other tertiary contacts in the RNA, demonstrating that tertiary interactions between helical domains are cooperative. Time-resolved footprinting experiments revealed that the P9 tetraloop mutation decreases the rate of direct folding to the native state and increases the fraction of the RNA population that initially misfolds. Our results suggest that the cooperative tertiary interactions enable a rapid and concerted folding of Azoarcus ribozyme, illustrating the association between cooperativity and the directness of the folding process.

\section{Materials and Methods}

\section{RNA Preparation and site-directed mutagenesis}

The L-9 Azoarcus ribozyme (195 nt) was transcribed from pAz-IVS DNA digested with Ear I as previously described. ${ }^{12}$ The RNA was resuspended in TE buffer $(10 \mathrm{mM}$ Tris-HCl, $\mathrm{pH} 7.5$, $0.1 \mathrm{mM}$ EDTA) before use. P9 loop mutants were prepared by mutating nucleotides A190 to U (GUAA) and A191 to G (GUGA) by PCR amplification of pAz-IVS and subsequent cloning into pUC18. The J5/5a receptor mutant (RGUAA) was engineered by introducing mutations C60 to G, A64 to C, G65 to U, U80 to A, U82 to G and G84 to C by inverse PCR amplification of pAz-IVS and cloning into pUC18. The compensatory double mutant, R'GUAA, was 
prepared by replacing A190 with U by direct PCR amplification of pAz-RGUAAIVS and subcloning into pUC18.

\section{Non-denaturing Gel Electrophoresis}

Refolding experiments were carried out in CE buffer (10 mM sodium cacodylate, $\mathrm{pH}$ 7.0, 0.1 mM EDTA), $10 \%$ (v/v) glycerol, $0.1 \%$ (w/v) xylene cyanol, and $0-50 \mathrm{mM} \mathrm{MgCl}_{2}$ at $50{ }^{\circ} \mathrm{C}$ as previously described. ${ }^{12}$ The fraction of native RNA, $f_{\mathrm{N}}$, was determined from the ratio of counts in band $\mathrm{N}$ relative to total counts in the lane. The fraction of native RNA as a function of $\mathrm{Mg}^{2+}$ concentration was normalized to the extent of folding at saturation and fit to the Hill equation. The maximum extent of folding at $50^{\circ} \mathrm{C}$ was typically $80 \%$, presumably reflecting a small population that remained trapped in misfolded conformations.

\section{RNase T1 Cleavage}

Partial RNase T1 digestion was carried out in $10 \mathrm{mM}$ Tris- $\mathrm{HCl}(\mathrm{pH}$ 7.5) plus 0-20 mM $\mathrm{MgCl}_{2}$ at $50^{\circ} \mathrm{C} .{ }^{12,14}$ Fractional saturation $(\bar{Y})$ of each protection was normalized to $100 \%$ observed at $20 \mathrm{mM} \mathrm{Mg}^{2+}$ and the data were fit to the Hill equation.

\section{Hydroxyl Radical Footprinting}

Fe(II)-EDTA-dependent hydroxyl radical cleavage reactions were carried out as previously described, ${ }^{12}$ except that $5^{\prime}{ }^{32} \mathrm{P}$-labeled RNA $(400,000 \mathrm{cpm})$ was incubated in CE buffer plus $0-50 \mathrm{mM} \mathrm{MgCl}$ for $15 \mathrm{~min}$ at $50^{\circ} \mathrm{C}$ and $5 \mathrm{~min}$ on ice, before the addition of Fenton reagents. Samples were heated to $95^{\circ} \mathrm{C}$ in a formamide dye before loading on an $8 \%(\mathrm{w} / \mathrm{v})$ sequencing gel. Sequence markers were prepared using RNase T1 or by cleavage of transcripts containing one phosphorothioate analogue (A $\alpha \mathrm{S}$ or $\mathrm{G} \alpha \mathrm{S})$ in $10 \mathrm{mM} \mathrm{I}_{2}$-ethanol. ${ }^{15}$

The relative extent of protection $(\bar{Y})$ was determined by comparing the intensity of bands in protected regions with cleavage products whose intensity does not change with $\mathrm{Mg}^{2+}$ concentration to correct for variations in sample recovery and loading. $1{ }^{16}$ Fractional saturation of each protection $(\bar{Y})$ versus $\mathrm{MgCl}_{2}$ concentration was fit to the Hill equation. The apparent $\mathrm{Mg}^{2+}$-dependent free energy associated with formation of each tertiary contact was calculated by linear extrapolation from the transition midpoint, $\Delta G_{\text {prot }}=-n_{H} R T \ln \left(C / C_{m}\right),{ }^{17,18}$ in which $n_{H}$ is the Hill coefficient, $C_{m}$ is the midpoint of the transition and $C$ is the $\mathrm{Mg}^{2+}$ concentration. This analysis assumes that an individual backbone contact is either completely formed or completely open. The free energy perturbation in the mutant relative to wild type was calculated from $\Delta \Delta G_{\text {prot }}=\Delta G_{\text {prot }}^{W T}-\Delta G_{\text {prot }}^{\text {mut }}$.

\section{Fast Fenton Footprinting}

Time-resolved Fe(II)-EDTA-dependent hydroxyl radical cleavage reactions were carried out as described. ${ }^{19}$ Folding reactions were initiated by mixing $15 \mu \mathrm{L} 5^{\prime 32} \mathrm{P}$-labeled RNA $(800,000$ cpm) in CE with and equal volume of $\mathrm{CE}+15 \mathrm{mM} \mathrm{MgCl}_{2}$ and $0.15 \%$ hydrogen peroxide using a Kintek ${ }^{\circledR} \mathrm{RQF}-3$ three syringe mixer, at $37^{\circ} \mathrm{C}$. After the desired folding delay, the samples were mixed with $1 \mathrm{mM} \mathrm{Fe}(\mathrm{II})$-EDTA via the third quench syringe. The samples were immediately expelled (5-10 ms) into a $20 \mu \mathrm{l}$ quench solution containing $3.2 \mathrm{M} \mathrm{NaCl}, 25 \mathrm{mM}$ EDTA $0.1 \mu \mathrm{g} / \mu \mathrm{l}$ carrier tRNA and $0.26 \mu \mathrm{g} / \mu \mathrm{l}$ glycogen. Under these conditions, the majority of cleavage occurs within 1-2 ms of Fe(II)-EDTA addition. ${ }^{19}$ The cleaved products were precipitated with three volumes of ethanol at $-20^{\circ} \mathrm{C}$ and separated on an $8 \%(\mathrm{w} / \mathrm{v})$ sequencing gel. The gels were analyzed and quantified as described above. The wild type and mutant data were fit to the single and double exponential rate equations, which were $\bar{Y}=A(1-\exp$ $\left.\left(-k_{\text {obs }} t\right)\right)$ and $\bar{Y}=A_{\text {fast }}\left(1-\exp \left(-k_{\text {fast }} t\right)\right)+A_{\text {slow }}\left(1-\exp \left(-k_{\text {slow }} t\right)\right)$, respectively. 


\section{Results}

\section{Perturbation of tetraloop-receptor docking}

GNRA tetraloops are common in RNA secondary structures, ${ }^{20}$ and their interactions with helical receptors elsewhere in the RNA stabilize its 3D architecture. ${ }^{21,22}$ The Azoarcus ribozyme contains two GAAA tetraloops. The tetraloop of paired region P9 docks with an 11nucleotide motif in joining region J5/5a, while the tetraloop at the end of $\mathrm{P} 2$ docks with J8/8a (Figure 1). ${ }^{23,24}$ These tetraloop-receptor interactions clamp together helices at the opposite ends of the catalytic core.

The stability of the P9-J5/5a tetraloop-receptor interaction was perturbed by combining different loop and receptor sequences that are known to have varying stability (Figure 1A). 25 The GAAA tetraloop in P9 was changed to GUAA and GUGA. Both GUAA and GUGA tetraloops conform to the GNRA consensus sequence, but they preferentially interact with CC:GG and CU:AG tandem base pairs, respectively. ${ }^{22,26}$ The $11 \mathrm{nt}$ receptor [CCUAA... UAUGG] in J5/5a, which is specific for GAAA tetraloops, was replaced with the sequence [GCUACU...AAGGC], which interacts strongly with GUAA tetraloops (RGUAA). ${ }^{27}$ Finally, we made a compensatory double mutant, R'GUAA, that combines the GUAA tetraloop with the GUAA tetraloop receptor.

\section{Mutants destabilize the compact state}

To determine if the disruption of native tetraloop-receptor interactions introduces new nonnative intermediates, native and non-native forms of wild-type and mutant RNAs were resolved by non-denaturing gel electrophoresis at $4-10{ }^{\circ} \mathrm{C}$ (Figure $2 \mathrm{~A}$ ). The native RNA (N) migrates more rapidly in the gel than the non-native conformers (nn). Under these conditions, further refolding is arrested after the RNA enters the gel matrix. ${ }^{28}$ Because the Azoarcus ribozyme folds rapidly, near-native intermediates $\left(\mathrm{I}_{\mathrm{c}}\right)$ are also trapped in the native conformation and migrate at the same speed as the native RNA $(\mathrm{N}) .{ }^{12}$ Thus, this method detects the $\mathrm{U}$ to $\mathrm{I}_{\mathrm{C}}$ transition, which involves assembly of helices in the ribozyme core.

Uniformly radiolabeled wild type and mutant ribozymes were incubated in increasing $\mathrm{Mg}^{2+}$ concentrations at $50{ }^{\circ} \mathrm{C}$ for $15 \mathrm{~min}$ and separated on a $10 \%$ native gel containing $3 \mathrm{mM}$ $\mathrm{MgCl}_{2}$. For the wild type RNA, the midpoint of the folding transition $\left(\mathrm{C}_{\mathrm{m}}\right)$ was $0.26( \pm 0.03)$ $\mathrm{mM}$, which is similar to the midpoint of the collapse transition monitored by SAXS $(0.34 \mathrm{mM}$ $\left.\mathrm{Mg}^{2+}\right) .{ }^{14}$ All of the mutated RNAs required higher $\mathrm{Mg}^{2+}$ concentrations to fold correctly $\left(\mathrm{C}_{\mathrm{m}}=0.31-0.47 \mathrm{mM}\right.$; Figure 2B). Even in $50 \mathrm{mM} \mathrm{MgCl}_{2}$, only $40-50 \%$ of the mutant RNA was native, compared with $\geq 80 \%$ of the wild type RNA. These results show that mutations in the tetraloop or in the receptor disfavor the formation of native-like intermediates, consistent with previous biochemical and SAXS results on the GUAA mutant obtained under slightly different conditions. ${ }^{14}$ Although compensation of the tetraloop-receptor interaction was expected to restore the stability of the folded ribozyme, ${ }^{27}$ the $\mathrm{R}^{\prime}$ GUAA double mutant did not fold as well as the wild type RNA.

Disruption of the interaction between $\mathrm{P} 9$ and J5/5a not only destabilized $\mathrm{I}_{\mathrm{C}}$, but also increased the conformational heterogeneity of the RNA population. First, all of the mutated RNAs, except RGUAA, exhibited two distinct populations of non-native intermediates (nn) (Figure S1).

Second, the mutants migrated more slowly than the wild-type RNA in the folded and unfolded states, indicating that none of the mutants is as compact as the wild-type RNA (S.C.,

unpublished results). Finally, when the RNA was preincubated in buffer without $\mathrm{Mg}^{2+}, 20 \%$ of wild-type RNA folded to $\mathrm{N}$ during the 5-15 seconds that the sample encounters $\mathrm{Mg}^{2+}$ in the gel running buffer $\left(4^{\circ} \mathrm{C}\right)$. By contrast, only $5-10 \%$ of the mutant RNAs folded correctly in this 
time (Figure 2). Thus, the wild type RNA has a greater probability of forming native-like conformations in a short time than the mutant RNA.

\section{Secondary structure and helix assembly}

We previously found that native gel mobility and metal ion-induced collapse correlates with the assembly of helices in the catalytic core, which become base paired in submillimolar $\mathrm{Mg}^{2+} .12,13$ To assess the effect of mutations on base pairing of core helices, the wild type RNA, GUAA and GUGA loop mutants were partially digested with RNase T1 in various $\mathrm{Mg}^{2+}$ concentrations. The cleavage patterns of all RNAs were similar to what we observed previously. ${ }^{12}$ Guanosines in $\mathrm{P} 2, \mathrm{P} 4, \mathrm{P} 5 / 5 \mathrm{a}, \mathrm{P} 6 \mathrm{a}$ and $\mathrm{P} 9$ were protected from cleavage in 10 $\mathrm{mM}$ Tris- $\mathrm{HCl}$ alone (Figure S2). G's in P3, P6, P7, P8a, J8/7 and P9.0 were protected from RNase T1 with increasing $\mathrm{Mg}^{2+}$, except G163-G166 in P8, which were first cleaved more strongly, then protected with $\mathrm{C}_{\mathrm{m}}=0.45 \mathrm{mM} \mathrm{MgCl}_{2}$.

As expected, G's in the core of the GUAA and GUGA tetraloop mutants required more $\mathrm{Mg}^{2+}\left(\mathrm{C}_{\mathrm{m}}=0.1-0.7 \mathrm{mM}\right)$ to become base paired than the same residues in the wild type RNA $\left(\mathrm{C}_{\mathrm{m}}=0.1-0.3 \mathrm{mM}\right)$ (Figures $3 \mathrm{~A}$ and $\mathrm{S} 3$; Table S1). Moreover, protection of individual G's from RNase $\mathrm{T} 1$ increased less cooperatively with respect to $\mathrm{Mg}^{2+}$ concentration in the mutants, and the $\mathrm{Mg}^{2+}$-dependence of forming individual base pairs varied more in the loop mutants compared with the wild type RNA (Figure 3B). Thus, destabilization of $\mathrm{I}_{\mathrm{C}}$ reduces the apparent cooperativity of helix assembly. This is unlikely to be due to direct perturbation of the RNA secondary structure by the base substitutions in P9, because G's far from P9 are as strongly affected as those nearby, and because base substitutions in the J5/5a receptor and in J6/7 produce similar results (Figure S2; ${ }^{14}$ ). Instead, we conclude that tertiary interactions between helical domains help drive the ensemble of base paired conformations toward a narrower subset of native-like structures.

\section{Cooperativity of tertiary folding}

As mutations in the P9 tetraloop destabilize the native ribozyme, we next asked whether loss of this tetraloop-receptor interaction influences the formation of tertiary interactions elsewhere in the RNA. The stabilities of individual tertiary interactions were probed by Fe(II)-EDTA dependent hydroxyl radical cleavage, which is sensitive to the solvent accessibility of the RNA backbone. ${ }^{29}$ The average accessibility of the RNA backbone reflects the equilibrium between open and closed states for each chain segment. This equilibrium depends on local fluctuations that expose the RNA backbone to solvent and on global unfolding. This same principle is used in hydrogen/deuterium exchange studies of protein folding. 30

If folding were perfectly cooperative (the RNA is either completely unfolded or completely folded), we expect residues in different parts of the RNA to become protected at the same $\mathrm{Mg}^{2+}$ concentration. If the tertiary interactions form independently of one another, we expect residues in different parts of the RNA to become protected at different $\mathrm{Mg}^{2+}$ concentrations. This is because individual tertiary contacts, which typically involve different types of noncovalent interactions, will have different free energies of formation and will depend differently on the bulk $\mathrm{Mg}^{2+}$ concentration. ${ }^{10,31}$

The hydroxyl radical cleavage pattern for the wild-type and mutant ribozymes were similar to each other and to our previous results on the wild-type RNA. ${ }^{12}$ Residues that are buried in the tertiary structure were increasingly protected from cleavage as the $\mathrm{Mg}^{2+}$ concentration was raised to $15 \mathrm{mM}$ (see Figure S5 for details), and the extent of backbone protection correlated with the increase in catalytic activity. In the wild type ribozyme, the midpoints for individual protected regions overlap within the experimental error $\left(\mathrm{C}_{\mathrm{m}}=1 \mathrm{mM} \mathrm{MgCl}_{2}, \mathrm{n}_{\mathrm{H}}=2\right.$; Figure $4 \mathrm{a}$ and Table 1), except for residues in $\mathrm{P} 4$, the $\mathrm{J} 5 / 5$ a receptor and $\mathrm{J} 4 / 5$, which require slightly 
more $\mathrm{Mg}^{2+}$ to be protected $\left(\mathrm{C}_{\mathrm{m}}=1.8 \mathrm{mM}\right)$. Nucleotides in $\mathrm{P} 4$ and $\mathrm{J} 4 / 5$ dock the $\mathrm{P} 1$ splice site helix,, 32 and may be compromised in our exon-less ribozyme. The formation of most tertiary contacts over a narrow range of $\mathrm{Mg}^{2+}$ concentration is consistent with a cooperative transition from $\mathrm{I}_{\mathrm{C}}$ to $\mathrm{N}$ in the wild type ribozyme.

\section{Energetic coupling between tertiary contacts}

Hydroxyl radical footprinting experiments showed that all of the tertiary contacts in the GUAA ribozyme appear at higher $\mathrm{Mg}^{2+}$ concentrations $\left(\mathrm{C}_{\mathrm{m}}=0.9\right.$ to $\left.2.5 \mathrm{mM} ; \mathrm{n}_{\mathrm{H}}=1\right)$ than the same contacts in the wild type ribozyme (Figures 4a and S6; Table 1). Other tetraloop and receptor mutations caused similar increases in the midpoints of the folding transitions (data not shown). Thus, disruption of the interaction between the P9 tetraloop and its receptor in J5/5a at one end of the ribozyme causes nearly equal destabilization of tertiary contacts elsewhere in the RNA. In addition, the GUAA mutation causes individual tertiary contacts to saturate over a broader range of $\mathrm{Mg}^{2+}$ concentration, suggesting an increased presence of folding intermediates.

Since the cooperativity and the midpoint of $\mathrm{Mg}^{2+}$-induced folding are related to the free energy gap between the unfolded and folded states, ${ }^{18,31}$ we obtained the free energy of forming individual tertiary contacts from the $\mathrm{Mg}^{2+}$-dependence of each hydroxyl radical protection (see Materials \& Methods). In the wild-type ribozyme, the free energies for forming individual tertiary contacts $\left(\Delta \mathrm{G}_{\mathrm{prot}}\right)$ ranged from -2.2 to $-4.0 \mathrm{kcal} / \mathrm{mol}$, whereas the GUAA tetraloop mutation made all of the tertiary contacts in the ribozyme less favorable, with free energies ranging from -1.4 to $-2.2 \mathrm{kcal} / \mathrm{mol}$ (Figure $4 \mathrm{~b}$ ). The largest perturbations to $\Delta \mathrm{G}_{\text {prot }}$ were observed in the J5/5a receptor, in $\mathrm{J} 3 / 4$ that base triples with $\mathrm{P} 6$, in $\mathrm{J} 8 / 8$ a that docks the $\mathrm{P} 2$ tetraloop, and in P9.0 that forms a reverse kink turn with P9. ${ }^{33}$ This global destabilization of tertiary structure is a hallmark of cooperative structures.

The thermodynamic destabilization at individual residues $(1.4-2.2 \mathrm{kcal} / \mathrm{mol})$ measured by hydroxyl radical footprinting is comparable to the global destabilization of the native state (1.2 $\mathrm{kcal} / \mathrm{mol}$ ) estimated from the $\mathrm{Mg}^{2+}$-dependence of catalytic activity. ${ }^{14}$ The Tetrahymena ribozyme and its P4-P6 domain are also destabilized by $2-4 \mathrm{kcal} / \mathrm{mol}$ upon disruption of peripheral tetraloop-receptor interactions. ${ }^{10,34,35}$

\section{Rapid folding of the wild type ribozyme}

The results above show that the $\mathrm{U}$ to $\mathrm{I}_{\mathrm{C}}$ and $\mathrm{I}_{\mathrm{C}}$ to $\mathrm{N}$ folding transitions become less cooperative when the RNA tertiary structure is destabilized. To determine whether this apparent loss of cooperativity also reduces the specificity of the folding pathways, we probed the folding kinetics of the Azoarcus ribozyme by time-resolved hydroxyl radical footprinting. By delivering the Fe(II)-EDTA with a rapid quench apparatus, changes in the RNA tertiary structure can be detected within $2-5$ milliseconds. ${ }^{19}$ This method was previously used to resolve folding intermediates of the Tetrahymena ribozyme. ${ }^{36}$

The folding kinetics of the Azoarcus ribozyme was measured by quantifying the changes in solvent accessibility of individual sites as a function of time (Figure S7). After addition of 15 $\mathrm{mM} \mathrm{Mg}{ }^{2+}$ at $37^{\circ} \mathrm{C}$, all of the nucleotides that are buried in the folded RNA were $80-100 \%$ protected from hydroxyl radical cleavage within $10 \mathrm{~ms}$ (Figure 5 and Figure S8). These results corroborate our earlier observation using X-ray footprinting that the Azoarcus ribozyme folds rapidly, without becoming trapped in metastable intermediates. ${ }^{12}$ The better time resolution of the rapid quench method, however, shortens our estimate of the folding time from $30-50 \mathrm{~ms}$ to $5-20 \mathrm{~ms}\left(\mathrm{k} \sim 50\right.$ to $150 \mathrm{~s}^{-1}$; Table S2). This is comparable to the folding times reported for tRNA $(10 \mathrm{~ms})^{37}$ and the $160 \mathrm{nt}$ P4-P6 RNA (35-350 ms), 38,39 and is much shorter than the typical folding time of large ribozymes. ${ }^{40}$ The rapid folding kinetics in the Azoarcus ribozyme 
is probably the outcome of a metal ion-induced collapse that specifically leads to native-like intermediates.

\section{Mutations reveals a rugged folding landscape}

To determine if destabilization of tertiary interactions introduces new folding intermediates, the folding kinetics of the wild type and GUAA ribozymes were compared (Figures 5 and S7). In contrast to the wild-type RNA, which folds in a single kinetic phase over the accessible time window, tertiary contacts in the GUAA ribozyme formed in two kinetic phases (Figures 5A and S8). Although 40-70\% of the RNA folded in the first $20 \mathrm{~ms}\left(\mathrm{k}_{\mathrm{fast}} \sim 50 \mathrm{~s}^{-1}\right)$, the remaining $30-60 \%$ of each backbone protection saturated over $30-200 \mathrm{~s}\left(\mathrm{k}_{\text {slow }} \sim 0.005\right.$ to $0.03 \mathrm{~s}^{-1}$; Table S2). Thus, the GUAA mutation slightly decreases the initial folding rate and reduces the fraction of the RNA population that rapidly forms the native tertiary structure. The small decrease in the initial folding rate may reflect the destabilization of $\mathrm{N}$. After the initial burst, tertiary contacts in J8/8a and J8/7 form 10,000-fold more slowly in the GUAA ribozyme than in the wild-type ribozyme.

These results demonstrate that destabilization of the tetraloop-receptor interaction allows new folding pathways to become populated (Figure 6). Loss of a tertiary contact introduces ruggedness in the otherwise smooth folding landscape of the wild type Azoarcus ribozyme. The more rugged energy landscape of the mutant RNA likely results from thermodynamic destabilization of a native-like, on-path compact intermediate, ${ }^{14}$ which decreases the specificity of the initial collapse transition in the mutant RNAs. Initial stopped-flow fluorescence experiments show that other tertiary mutations in the Azoarcus ribozyme also increase the extent of misfolding (S.C. and S.W., unpublished). By contrast, similar mutational studies on both isolated P4-P6 domain and the entire Tetrahymena ribozyme showed milder effects on the folding kinetics. ${ }^{34,35,38}$ This may reflect the propensity of those RNAs to fold via partially misfolded intermediates, so that the observed folding rate depends on structural rearrangements later in the folding process rather than on the specificity of the initial collapse.

\section{Discussion}

Our results on the Azoarcus ribozyme establish a correlation between cooperativity and accuracy in RNA folding that was suggested in earlier work on the Tetrahymena ribozyme.

31 Because RNA structures are stabilized by many weak, non-covalent interactions, the stability of the folded RNA increases with the number of energetically favorable interactions that are present in the native state but not in the unfolded RNA. Theoretical models and experiments show that the cooperativity, stability and folding kinetics all depend on the degree to which the interactions uniquely specify the three-dimensional structure. ${ }^{3,41,42}$ As the interactions that stabilize the native state become more cooperative, intermediate structures are less populated, and the free energy gap between the native and unfolded states becomes larger.

Strong cooperativity among native interactions (and a low potential for topological frustration) produces a smooth free energy landscape that allows most of the molecules to faithfully collapse toward the native state. ${ }^{2}$ By contrast, low cooperativity among native interactions creates a rough free energy landscape and increases the probability that some molecules in the population become kinetically trapped in misfolded intermediates. ${ }^{5}$ Our results on the Azoarcus ribozyme show that tertiary interactions not only stabilize the $\mathrm{I}_{\mathrm{C}}$ and $\mathrm{N}$ states, but also contribute significantly to the accuracy and the speed of RNA folding.

The presence of tertiary interactions in $\mathrm{I}_{\mathrm{C}}$ is unexpected, because backbone contacts are not directly detected by hydroxyl radical footprinting under conditions that populate $\mathrm{I}_{\mathrm{C}}$. However, the conclusion that tertiary interactions stabilize $\mathrm{I}_{\mathrm{C}}$ is supported by thermal melting data and by SAXS experiments which measured the global collapse transition in the GUAA mutant and 
in ribozymes with mutations in $\mathrm{P} 3$ and the central triple helix. ${ }^{14}$ Studies on the P4-P6 RNA and the bI5 ribozyme also found evidence for native interactions in compact RNA intermediates. ${ }^{43}$ One possibility is that the tertiary interactions in $\mathrm{I}_{\mathrm{C}}$ are dynamic, allowing solvent (and hydroxyl radical) to enter the RNA interior.

\section{Specificity of helix assembly}

The extent of misfolding in RNA is usually attributed to the fact that a single sequence can form more than one stable secondary structure. ${ }^{44}$ While the potential for mispairing is important, our results suggest that tertiary interactions restrict the number of base paired configurations that are allowed, significantly increasing the specificity of self-assembly. Mutations in $\mathrm{P} 9$ or J5/5a not only diminish the cooperativity of base pairing with respect to $\mathrm{Mg}^{2+}$ concentration, but also reduce the correlation between base pairs in different parts of the RNA.

There are several examples in which tertiary folding changes the secondary structure of the RNA, such as the alpha operon mRNA leader, ${ }^{45}$ the P5abc subdomain of the Tetrahymena ribozyme, ${ }^{46}$ and a stem-loop in the Varkud Satellite ribozyme. ${ }^{47}$ Thus, although secondary structures are typically more stable than tertiary interactions in RNA, tertiary interactions can provide enough free energy to shift the equilibrium between different secondary structures. Our results suggest that this is an important mechanism for prejudicing the ensemble of folding intermediates toward native-like structures.

In the Azoarcus ribozyme, the majority of base pairs in the core of the ribozyme form during the collapse transition from $U$ to $\mathrm{I}_{\mathrm{C}}$, which requires counterions such as $\mathrm{Mg}^{2+}$. SAXS experiments showed that tertiary interactions, including docking of the P9 tetraloop with J5/5a, stabilize $\mathrm{I}_{\mathrm{C}}{ }^{14}$ Because tertiary interactions often connect nucleotides that are far apart in the primary sequence, they constrain the global conformation of the RNA more powerfully than base pairs, which more often join nearby residues. In the Azoarcus ribozyme, the cooperativity of tertiary interactions not only stabilizes the folded RNA but make the collapse transition more specific.

\section{Direct and indirect kinetic folding pathways}

Because the initial collapse transition is specific and $\mathrm{I}_{\mathrm{C}}$ contains mostly native-like structures, $\geq 80 \%$ of the wild type Azoarcus ribozyme folds within 5-20 ms in our experiments. By contrast, our time-resolved footprinting results show that disruption of native tertiary interactions between $\mathrm{P} 9$ and $\mathrm{J} 5 / 5 \mathrm{a}$ in the mutants reduces the size of the fast folding population and increases the flux through alternative folding pathways (Figure 6). We also found that the initial folding transition appears slightly slower in the GUAA mutant than in the wild type ribozyme. The observation that this mutation changes the partitioning between kinetic folding pathways supports the prediction that the smoothness of the folding landscape is directly related to the stability of the tertiary structure.

It is interesting to consider why some group I ribozymes fold rapidly, such as the Azoarcus ribozyme ${ }^{12}$ and the ribozyme from Candida large subunit rRNA, ${ }^{48}$ while others such as the Tetrahymena ribozyme tend to become trapped in misfolded intermediates. ${ }^{49}$ In the Tetrahymena ribozyme, the native $\mathrm{P} 3$ helix is replaced by a stable alternative pairing (alt P3), 50 and the kinetic partitioning toward the direct (fast) folding pathway is sensitive to the relative stability of P3 and alt P3. ${ }^{51}$ Thus, the potential for mispairing contributes to the roughness of the free energy landscape.

Base pairing cannot be the only factor that determines the fidelity of the folding process, however, as the Azoarcus and Candida ribozymes can also mispair although they form less 
stable alternatives to $\mathrm{P} 3$ than the Tetrahymena ribozyme. ${ }^{48}$ A critical difference, however, is that the $\mathrm{P} 2$ and $\mathrm{P} 9$ tetraloops can only dock with their receptors in the Azoarcus ribozyme when the core helices are correctly assembled. Thus, the formation of these and other tertiary interactions during the collapse transition preferentially stabilizes native helices relative to mispaired structures. By contrast, both correctly base paired and mispaired conformations of the Tetrahymena ribozyme are greatly stabilized by tertiary interactions between the peripheral $\mathrm{P} 2, \mathrm{P} 2.1, \mathrm{P} 5 \mathrm{c}$ and P9a helices. ${ }^{52}$ Mutations that destabilize these peripheral tertiary interactions accelerate folding, confirming that they help lock the Tetrahymena ribozyme in a misfolded state. 34,53

\section{Cooperativity and thermostability}

The Azoarcus ribozyme is an unusually stable RNA, remaining active up to $75{ }^{\circ} \mathrm{C}$ or in $5 \mathrm{M}$ urea. ${ }^{23}$ This is surprising because the free energy changes associated with the formation of tertiary interactions in the $\mathrm{I}_{\mathrm{C}}$ to $\mathrm{N}$ transition are only $2-3 \mathrm{kcal} / \mathrm{mol}$ in $10 \mathrm{mM} \mathrm{MgCl} 2$ (Table 1). The thermostability of Azoarcus ribozyme, however, can also be explained by the specificity of the folding transitions from $\mathrm{U}$ to $\mathrm{I}_{\mathrm{C}}$ and $\mathrm{I}_{\mathrm{C}}$ to $\mathrm{N}$. In native conditions, thermal fluctuations that result in transient opening of the tertiary structure are expected to produce native-like intermediates that can quickly reform the native structure. By contrast, transient unfolding of the Tetrahymena ribozyme, which loses activity above $55^{\circ} \mathrm{C},{ }^{54}$ produces non-native conformations which cannot easily refold to N. ${ }^{55}$ This may explain why the Tetrahymena ribozyme denatures more easily than the Azoarcus ribozyme, despite the fact that it is twice the size and contains many more tertiary interactions.

Nucleotide swapping experiments between the Azoarcus ribozyme and a less stable relative from Anabaena pre-tRNA suggested that the thermostability of the Azoarcus ribozyme originates from stronger hydrogen bonding interactions within the catalytic core. ${ }^{56} \mathrm{~A}$ similar conclusion was reached from selection of a thermostable variant of the Tetrahymena ribozyme 54,57 and comparisons of the specificity (S) domains of mesophilic and thermophilic RNase P ribozymes. 58

In another study that compared the stability of the catalytic (C) domains of mesophilic and thermophilic RNase P RNAs, folding of the thermophilic RNA was more cooperative with respect to $\mathrm{Mg}^{2+}$ concentration and associated with greater acquisition of structure than folding of its mesophilic relative. ${ }^{59}$ Greater cooperativity in the thermophilic ribozyme was achieved by raising the free energy of an equilibrium folding intermediate, so that the intermediate is no longer populated. ${ }^{59}$ Thus, in both the Azoarcus ribozyme and in the thermophilic RNase P, the stability of the native state is directly related to the cooperativity of the tertiary structure.

\section{Conclusion}

Our equilibrium and time-resolved footprinting experiments demonstrate that native tertiary interactions in the Azoarcus ribozyme form cooperatively. By stabilizing a native-like intermediate, tertiary interactions also enable the rapid and concerted folding of Azoarcus ribozyme. Although RNA folding pathways are often thought to depend on which base pairs form in advance of the tertiary contacts, our results suggest that tertiary interactions between helices make the process of helix assembly more specific and more likely to produce the native architecture. These results strengthen the hypothesis that the early events have significant implications for later events in a folding pathway. ${ }^{42,60}$ They also illustrate the link between thermodynamic cooperativity and the directness of the folding process in RNA.

\section{Supplementary Material}

Refer to Web version on PubMed Central for supplementary material. 


\section{Acknowledgments}

The authors thank S. Mitra, I. Shcherbakova, J. Schlatterer and M. Brenowitz for assistance with Kintek experiments. We also thank D. Thirumalai for helpful discussion. This work was supported by a grant from the NIH (GM60809).

\section{References}

1. Dill KA. Protein Sci 1999;8:1166. [PubMed: 10386867]

2. Thirumalai D, Hyeon C. Biochemistry 2005;44:4957. [PubMed: 15794634]

3. Brion P, Westhof E. Annu. Rev. Biophys. Biomol. Struct 1997;26:113. [PubMed: 9241415]

4. Tinoco IJ, Bustamante C. J. Mol. Biol 1999;293:271. [PubMed: 10550208]

5. Thirumalai D, Woodson SA. Acc. Chem. Res 1996;29:433.

6. Treiber DK, Williamson JR. Curr. Opin. Struct. Biol 1999;9:339. [PubMed: 10361090]

7. (a) Freier SM, Kierzek R, Jaeger JA, Sugimoto N, Caruthers MH, Neilson T, Turner DH. Proc. Natl. Acad. Sci. U.S.A 1986;83:9373. [PubMed: 2432595] (b) Mathews DH, Sabina J, Zuker M, Turner DH. J. Mol. Biol 1999;288:911. [PubMed: 10329189] (c) Siegfried NA, Metzger SL, Bevilacqua PC. Biochemistry 2007;46:172. [PubMed: 17198387]

8. Silverman SK, Cech TR. Biochemistry 1999;38:8691. [PubMed: 10393544]

9. (a) Nixon PL, Cornish PV, Suram SV, Giedroc DP. Biochemistry 2002;41:10665. [PubMed: 12186552] (b) Moody EM, Bevilacqua PC. J. Am. Chem. Soc 2003;125:16285. [PubMed: 14692769]

10. Ralston CY, He Q, Brenowitz M, Chance MR. Nat. Struct. Biol 2000;7:371. [PubMed: 10802732]

11. Reinhold-Hurek B, Shub DA. Nature 1992;357:173. [PubMed: 1579169]

12. Rangan P, Masquida B, Westhof E, Woodson SA. Proc. Natl. Acad. Sci. U.S.A 2003;100:1574. [PubMed: 12574513]

13. Perez-Salas UA, Rangan P, Krueger S, Briber RM, Thirumalai D, Woodson SA. Biochemistry 2004;43:1746. [PubMed: 14769052]

14. Chauhan S, Caliskan G, Briber RM, Perez-Salas U, Rangan P, Thirumalai D, Woodson SA. J. Mol. Biol 2005;353:1199. [PubMed: 16214167]

15. Ryder SP, Ortoleva-Donnelly L, Kosek AB, Strobel SA. Methods Enzymol 2000;317:92. [PubMed: 10829274]

16. Sclavi B, Woodson S, Sullivan M, Chance M, Brenowitz M. Methods Enzymol 1998;295:379. [PubMed: 9750229]

17. Cantor, CR.; Schimmel, PR., editors. The behavior of biological macromolecules. III. W. H. Freeman; San Francisco: 1980. p. 1371

18. Fang X, Pan T, Sosnick TR. Biochemistry 1999;38:16840. [PubMed: 10606517]

19. Shcherbakova I, Mitra S, Beer RH, Brenowitz M. Nucleic Acids Res 2006;34:e48. [PubMed: 16582097]

20. Woese CR, Winker S, Gutell RR. Proc. Natl. Acad. Sci. U.S.A 1990;87:8467. [PubMed: 2236056]

21. (a) Murphy FL, Cech TR. J. Mol. Biol 1994;236:49. [PubMed: 8107125] (b) Costa M, Michel F. EMBO J 1995;14:1276. [PubMed: 7720718]

22. Jaeger L, Michel F, Westhof E. J. Mol. Biol 1994;236:1271. [PubMed: 7510342]

23. Tanner M, Cech T. RNA 1996;2:74. [PubMed: 8846298]

24. Ikawa Y, Naito D, Aono N, Shiraishi H, Inoue T. Nucleic Acids Res 1999;27:1859. [PubMed: 10101194]

25. Jaeger L, Westhof E, Leontis NB. Nucleic Acids Res 2001;29:455. [PubMed: 11139616]

26. Pley HW, Flaherty KM, McKay DB. Nature 1994;372:111. [PubMed: 7526219]

27. Costa M, Michel F. EMBO J 1997;16:3289. [PubMed: 9214644]

28. Emerick VL, Woodson SA. Proc. Natl. Acad. Sci. U.S.A 1994;91:9675. [PubMed: 7937871]

29. Tullius TD, Greenbaum JA. Curr Opin Chem Biol 2005;9:127. [PubMed: 15811796]

30. (a) Englander SW, Mayne L, Bai Y, Sosnick TR. Protein Sci 1997;6:1101. [PubMed: 9144782] (b) Chamberlain AK, Marqusee S. Structure 1997;5:859. [PubMed: 9261079]

31. Pan J, Thirumalai D, Woodson SA. Proc. Natl. Acad. Sci. U.S.A 1999;96:6149. [PubMed: 10339556] 
32. (a) Wang JF, Cech TR. Science 1992;256:526. [PubMed: 1315076] (b) Strobel SA, Cech TR. Science 1995;267:675. [PubMed: 7839142]

33. Strobel SA, Adams PL, Stahley MR, Wang J. RNA 2004;10:1852. [PubMed: 15547133]

34. Treiber DK, Williamson JR. J. Mol. Biol 2001;305:11. [PubMed: 11114243]

35. Young BT, Silverman SK. Biochemistry 2002;41:12271. [PubMed: 12369814]

36. Laederach A, Shcherbakova I, Liang MP, Brenowitz M, Altman RB. J. Mol. Biol 2006;358:1179. [PubMed: 16574145]

37. Cole PE, Crothers DM. Biochemistry 1972;11:4368. [PubMed: 4562591]

38. Deras ML, Brenowitz M, Ralston CY, Chance MR, Woodson SA. Biochemistry 2000;39:10975. [PubMed: 10998234]

39. Silverman SK, Deras ML, Woodson SA, Scaringe SA, Cech TR. Biochemistry 2000;39:12465. [PubMed: 11015228]

40. (a) Zarrinkar PP, Williamson JR. Science 1994;265:918. [PubMed: 8052848] (b) Fang XW, Pan T, Sosnick TR. Nat. Struct. Biol 1999;6:1091. [PubMed: 10581546] (c) Swisher JF, Su LJ, Brenowitz M, Anderson VE, Pyle AM. J. Mol. Biol 2002;315:297. [PubMed: 11786013] (d) Xiao M, Leibowitz MJ, Zhang Y. Nucleic Acids Res 2003;31:3901. [PubMed: 12853605]

41. (a) Go N. Annu. Rev. Biophys. Bioeng 1983;12:183. [PubMed: 6347038] (b) Creighton TE, Darby NJ, Kemmink J. FASEB J 1996;10:110. [PubMed: 8566531] (c) Onuchic JN, Luthey-Schulten Z, Wolynes PG. Annu Rev Phys Chem 1997;48:545. [PubMed: 9348663] (d) Luque I, Leavitt SA, Freire E. Annu Rev Biophys Biomol Struct 2002;31:235. [PubMed: 11988469] (e) Pyle AM, Fedorova O, Waldsich C. Trends Biochem. Sci 2007;32:138. [PubMed: 17289393]

42. Sosnick TR, Pan T. Curr. Opin. Struct. Biol 2003;13:309. [PubMed: 12831881]

43. (a) Das R, Kwok LW, Millett IS, Bai Y, Mills TT, Jacob J, Maskel GS, Seifert S, Mochrie SG, Thiyagarajan P, Doniach S, Pollack L, Herschlag D. J. Mol. Biol 2003;332:311. [PubMed: 12948483] (b) Buchmueller KL, Weeks KM. Biochemistry 2003;42:13869. [PubMed: 14636054]

44. (a) Adams A, Lindahl T, Fresco JR. Proc. Natl. Acad. Sci. U.S.A 1967;57:1684. [PubMed: 5231404] (b) Uhlenbeck OC. RNA 1995;1:4. [PubMed: 7489487] (c) Herschlag D. J. Biol. Chem 1995;270:20871. [PubMed: 7545662]

45. Gluick TC, Gerstner RB, Draper DE. J. Mol. Biol 1997;270:451. [PubMed: 9237910]

46. Wu M, Tinoco I Jr. Proc. Natl. Acad. Sci. U.S.A 1998;95:11555. [PubMed: 9751704]

47. Andersen AA, Collins RA. Proc. Natl. Acad. Sci. U.S.A 2001;98:7730. [PubMed: 11427714]

48. Zhang L, Xiao M, Lu C, Zhang Y. RNA 2005;11:59. [PubMed: 15574515]

49. (a) Pan J, Thirumalai D, Woodson SA. J. Mol. Biol 1997;273:7. [PubMed: 9367740] (b) Rook MS, Treiber DK, Williamson JR. J. Mol. Biol 1998;281:609. [PubMed: 9710534]

50. Pan J, Woodson SA. J. Mol. Biol 1998;280:597. [PubMed: 9677291]

51. (a) Pan J, Deras ML, Woodson SA. J. Mol. Biol 2000;296:133. [PubMed: 10656822] (b) Russell R, Zhuang X, Babcock HP, Millett IS, Doniach S, Chu S, Herschlag D. Proc. Natl. Acad. Sci. U.S.A 2002;99:155. [PubMed: 11756689]

52. (a) Banerjee AR, Jaeger JA, Turner DH. Biochemistry 1993;32:153. [PubMed: 8418835] (b) Laggerbauer B, Murphy FL, Cech TR. EMBO J 1994;13:2669. [PubMed: 8013466] (c) Lehnert V, Jaeger L, Michel F, Westhof E. Chem. Biol 1996;3:993. [PubMed: 9000010]

53. Pan J, Woodson SA. J. Mol. Biol 1999;294:955. [PubMed: 10588899]

54. Guo F, Cech TR. Nat. Struct. Biol 2002;9:855. [PubMed: 12368901]

55. Hopkins JF, Woodson SA. Nucleic Acids Res 2005;33:5763. [PubMed: 16221975]

56. Ikawa Y, Naito D, Shiraishi H, Inoue T. Nucleic Acids Res 2000;28:3269. [PubMed: 10954594]

57. Guo F, Gooding AR, Cech TR. RNA 2006;12:387. [PubMed: 16431981]

58. Baird NJ, Srividya N, Krasilnikov AS, Mondragon A, Sosnick TR, Pan T. RNA 2006;12:598. [PubMed: 16581805]

59. Fang XW, Golden BL, Littrell K, Shelton V, Thiyagarajan P, Pan T, Sosnick TR. Proc. Natl. Acad. Sci. U.S.A 2001;98:4355. [PubMed: 11296284]

60. Thirumalai D, Lee N, Woodson SA, Klimov D. Annu. Rev. Phys. Chem 2001;52:751. [PubMed: 11326079] 
61. Adams PL, Stahley MR, Kosek AB, Wang J, Strobel SA. Nature 2004;430:45. [PubMed: 15175762] 
A

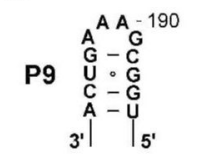

WT

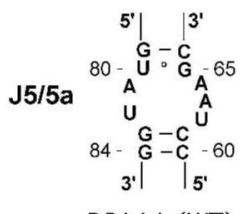

RGAAA (WT)

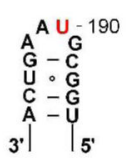

GUAA

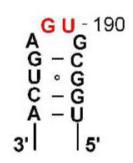

GUGA

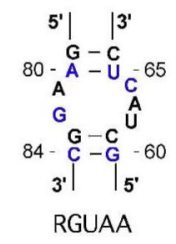

B

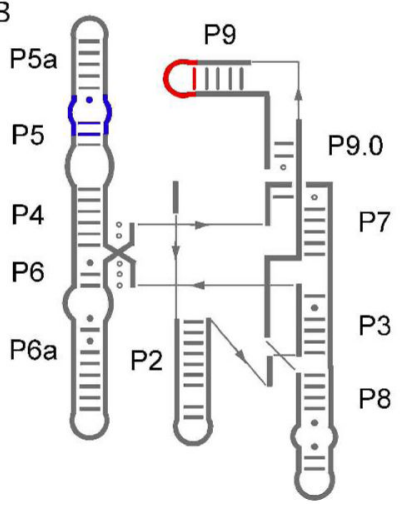

C

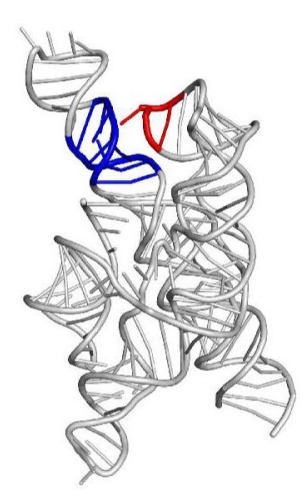

Figure 1. Mutagenesis of tertiary interactions in the Azoarcus ribozyme

A. Sequence of P9 tetraloop and J5/5a 11-nt canonical receptor motif. Base substitutions are shown in red and blue, respectively. B. Secondary structure of the L-9 ribozyme. P9-tetraloop, red; J5/5a-receptor, blue. C. Ribbon diagram of the three-dimensional structure (PDB 1u6b; 61 ) colored as in B; created with Pymol (DeLano Scientific; http://pymol.sourceforge.net). 

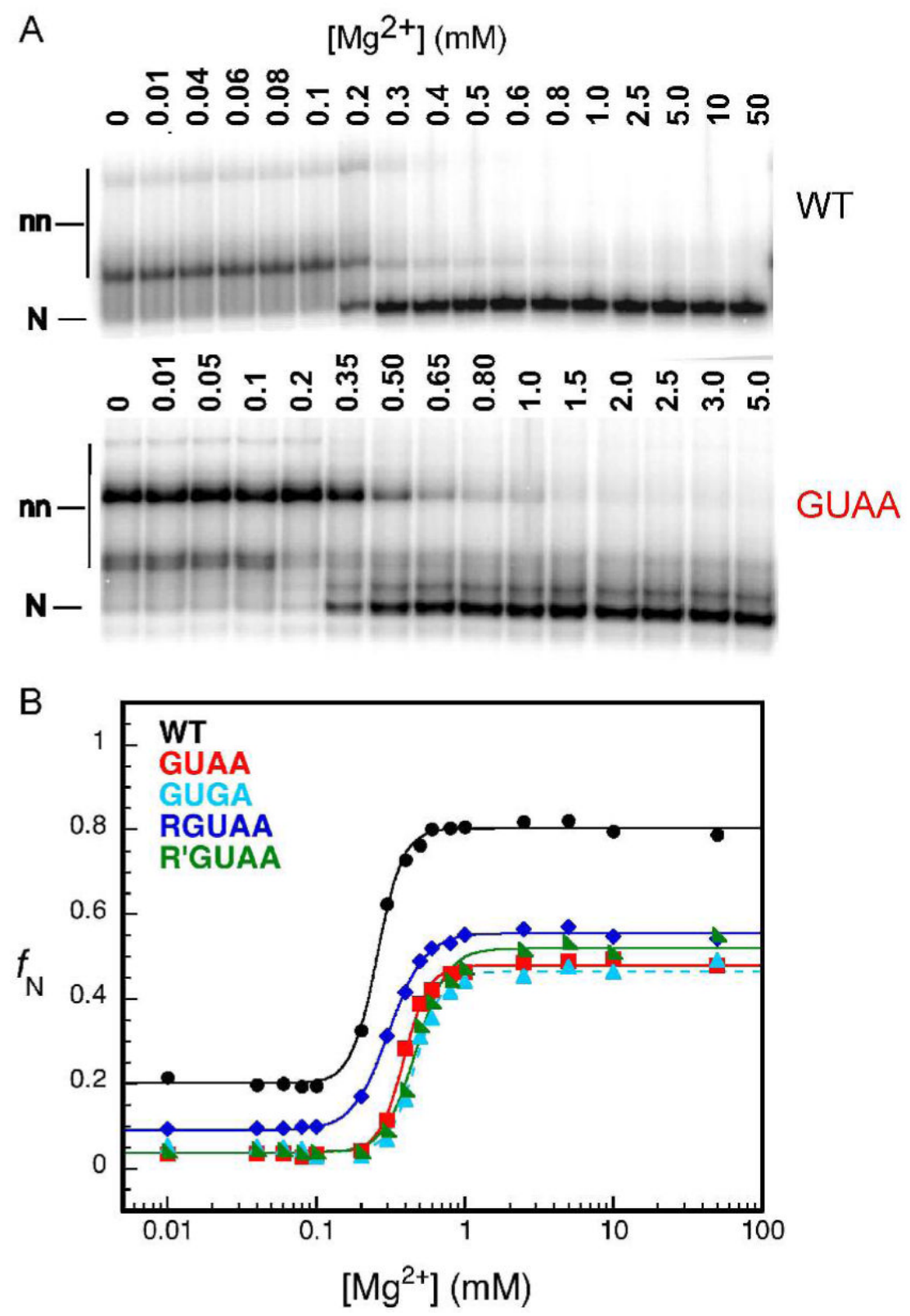

Figure 2. Folding of Azoarcus ribozyme by native PAGE

A. WT, wild-type ribozyme; GUAA, P9 tetraloop mutation. Bands nn, non-native folding intermediates; N, native RNA. Native PAGE for other mutants are shown in Figure S1. B. $\mathrm{Mg}^{2+}$-dependence of folding. The fraction of native RNA was fit to the Hill equation (see Methods). Wild-type: black circles $\left(\mathrm{C}_{\mathrm{m}}=0.26 \pm 0.01 \mathrm{mM}, \mathrm{n}_{\mathrm{H}}=4.9 \pm 0.3\right)$; GUAA: red squares $\left(\mathrm{C}_{\mathrm{m}}=0.43 \pm 0.01 \mathrm{mM}, \mathrm{n}_{\mathrm{H}}=3.9 \pm 0.3\right)$; GUGA: cyan triangles $\left(\mathrm{C}_{\mathrm{m}}=0.47 \pm 0.01 \mathrm{mM}, \mathrm{n}_{\mathrm{H}}=\right.$ $4.9 \pm 0.5)$; RGUAA: blue diamonds $\left(\mathrm{C}_{\mathrm{m}}=0.31 \pm 0.01 \mathrm{mM}, \mathrm{n}_{\mathrm{H}}=3.6 \pm 0.2\right)$ and R'GUAA: green inverted traingles $\left(C_{m}=0.47 \pm 0.01 \mathrm{mM}, \mathrm{n}_{\mathrm{H}}=4.1 \pm 0.4\right)$. 

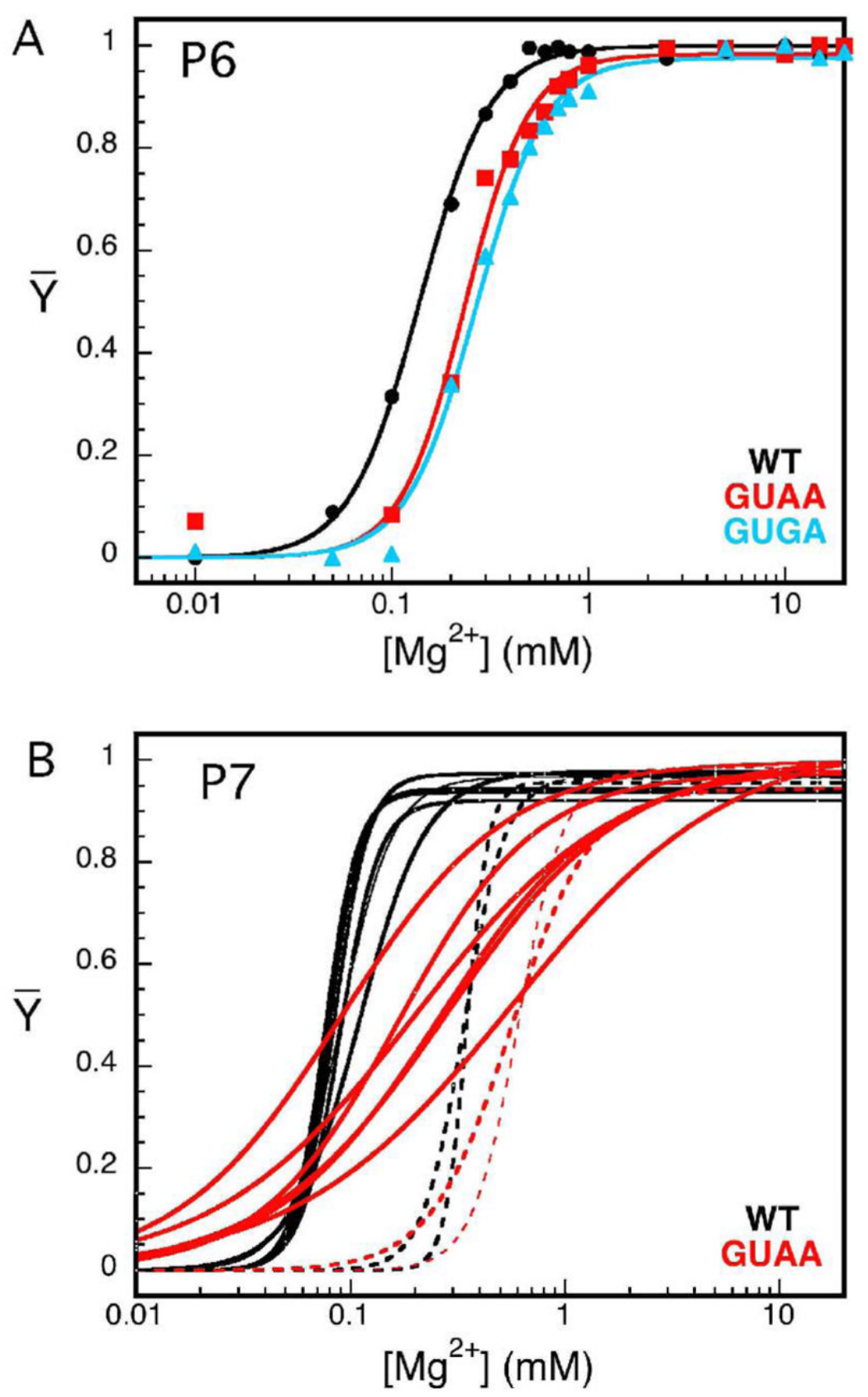

Figure 3. Helix assembly in the Azoarcus ribozyme

Formation of core helices was monitored by partial digestion with RNase T1. A. $\mathrm{Mg}^{2+}$ dependence of RNase T1 protection in P6 (nt 122-126). Wild-type: black circles $\left(\mathrm{C}_{\mathrm{m}}=0.14 \pm\right.$ $\left.0.01 \mathrm{mM}, \mathrm{n}_{\mathrm{H}}=2.5 \pm 0.11\right)$; GUAA: red squares $\left(\mathrm{C}_{\mathrm{m}}=0.23 \pm 0.02 \mathrm{mM}, \mathrm{n}_{\mathrm{H}}=2.7 \pm 0.3\right)$; GUGA: cyan triangles $\left(\mathrm{C}_{\mathrm{m}}=0.27 \pm 0.01 \mathrm{mM}, \mathrm{n}_{\mathrm{H}}=2.5 \pm 0.2\right)$. B. Fractional saturation of RNase $\mathrm{T} 1$ protection at $\mathrm{G}$ 's throughout the secondary structure (fitted curves only). Wild-type (black) and GUAA (red). Dashed lines represent nt in P3 and P8. Data for individual positions are shown in Figure S3 and Table S1. 

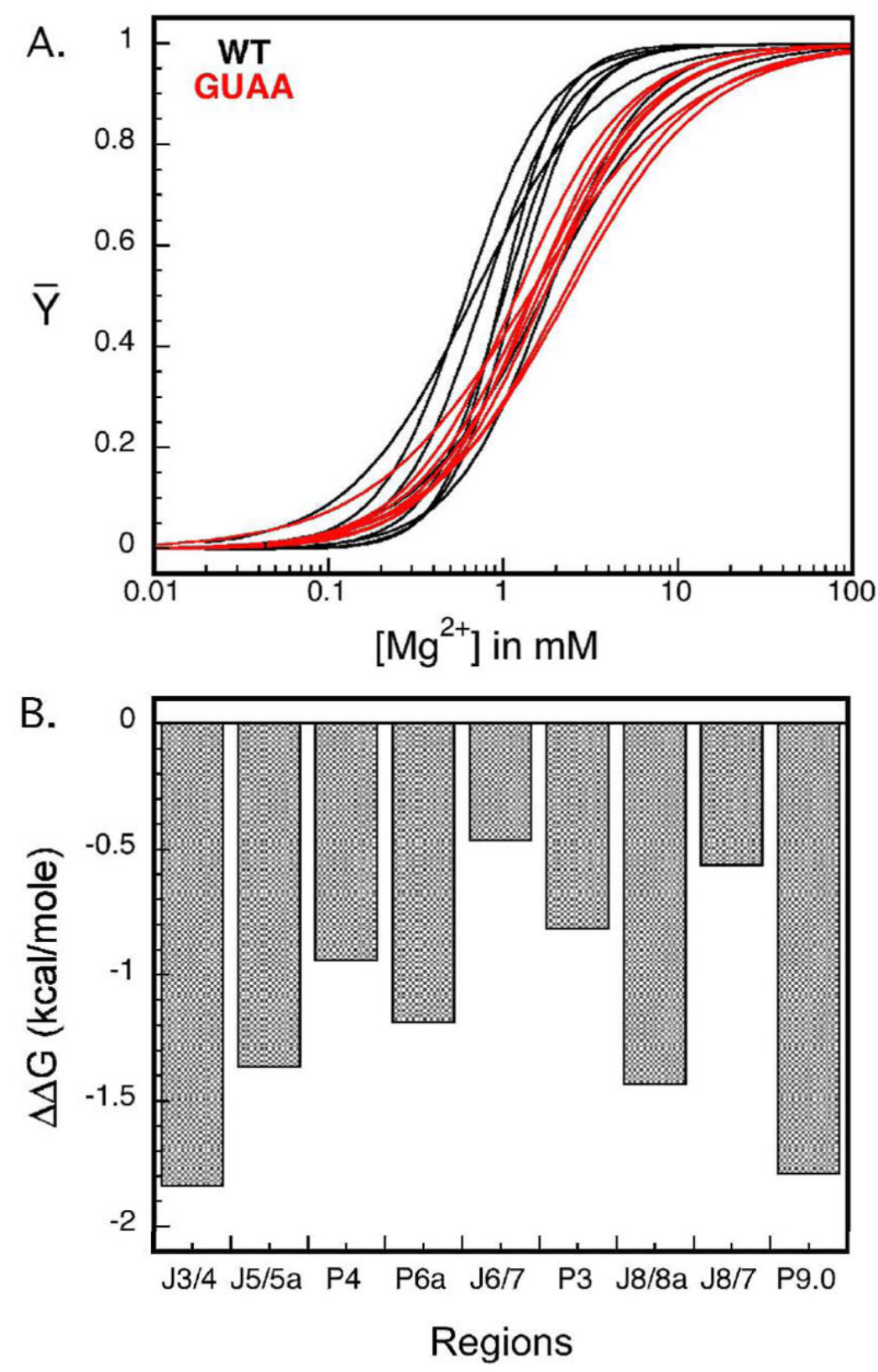

Figure 4. $\mathrm{Mg}^{2+}$-dependence of tertiary contacts

Solvent accessibility of the RNA backbone was probed by Fe(II)-dependent hydroxyl radical cleavage. A. Fractional saturation of protections from hydroxyl radicals across all tertiary contacts in wild-type (black) and GUAA (red) ribozymes. Data for individual positions are shown in Figure S6. All data were fit to the Hill equation assuming a single open and closed state for each residue. B. Free energy of forming of individual backbone contacts $\left(\Delta \Delta \mathrm{G}_{\mathrm{prot}}\right)$ in the wild-type ribozyme relative to the GUAA ribozyme in $15 \mathrm{mM} \mathrm{MgCl}_{2}$ (see Methods). 

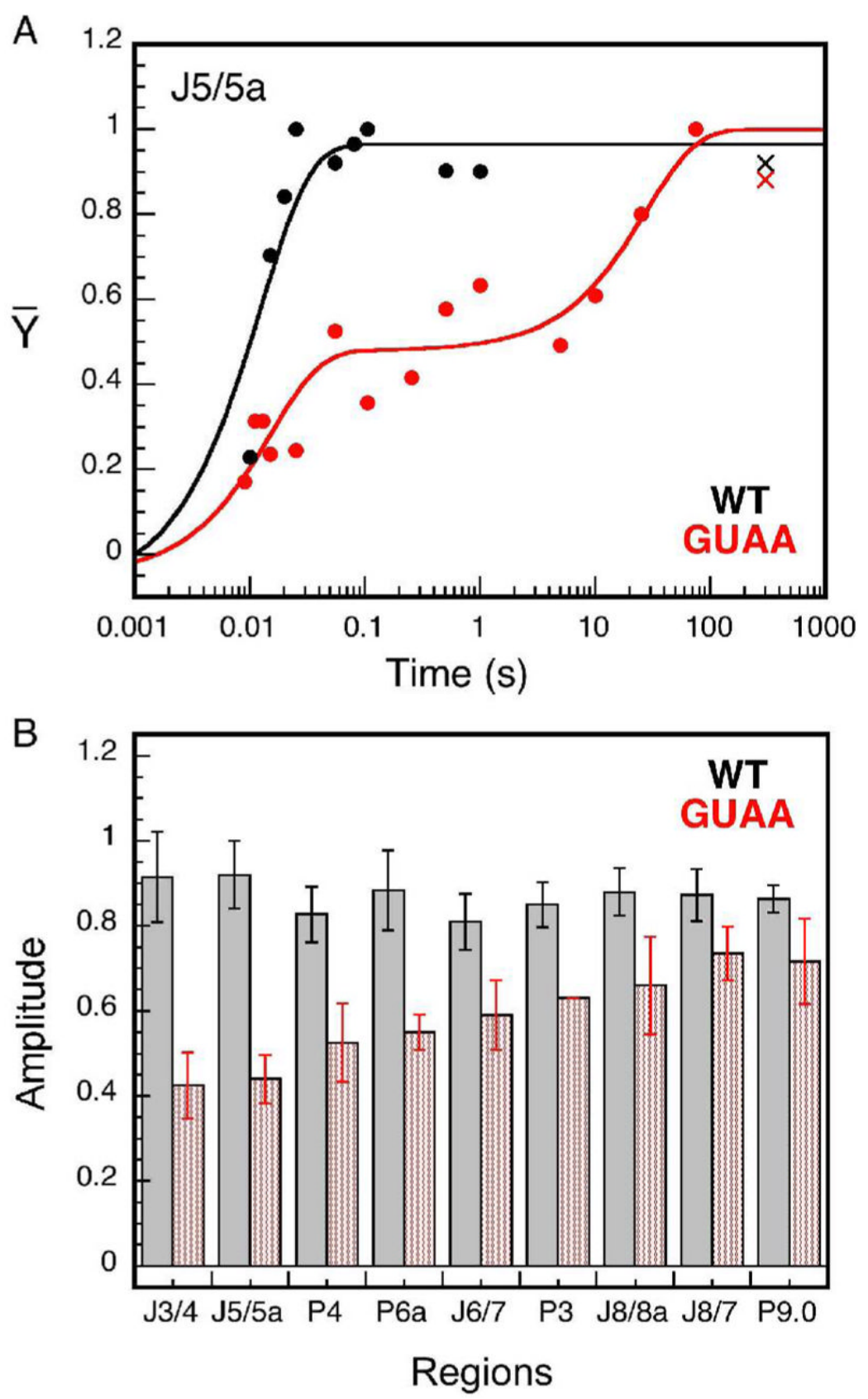

Figure 5. Tertiary folding kinetics of the Azoarcus ribozyme

A. Fractional saturation of protection in P5/5a (nt 62-63) from time-resolved Fe(II)-EDTA hydroxyl radical cleavage. Wild type: closed circles $\left(\mathrm{k}=96 \pm 20 \mathrm{~s}^{-1}, \mathrm{~A}=0.97 \pm 0.06\right)$; GUAA: open circles $\left(\mathrm{k}_{\mathrm{fast}}=56 \pm 16 \mathrm{~s}^{-1}, \mathrm{~A}_{\text {fast }}=0.48 \pm 0.04 ; \mathrm{k}_{\text {slow }}=0.04 \pm 0.02 \mathrm{~s}, \mathrm{~A}_{\text {slow }}=0.52 \pm\right.$ $0.01)$. Data were fit to single or double exponential rate equations. Cross, RNA pre-folded in $15 \mathrm{mM} \mathrm{MgCl}_{2}$. The data for other positions are presented in Figure S8 and Table S2. B.

Amplitude of the burst phase across all tertiary contacts in the ribozyme. Wild-type, shaded bars; GUAA, open bars. 


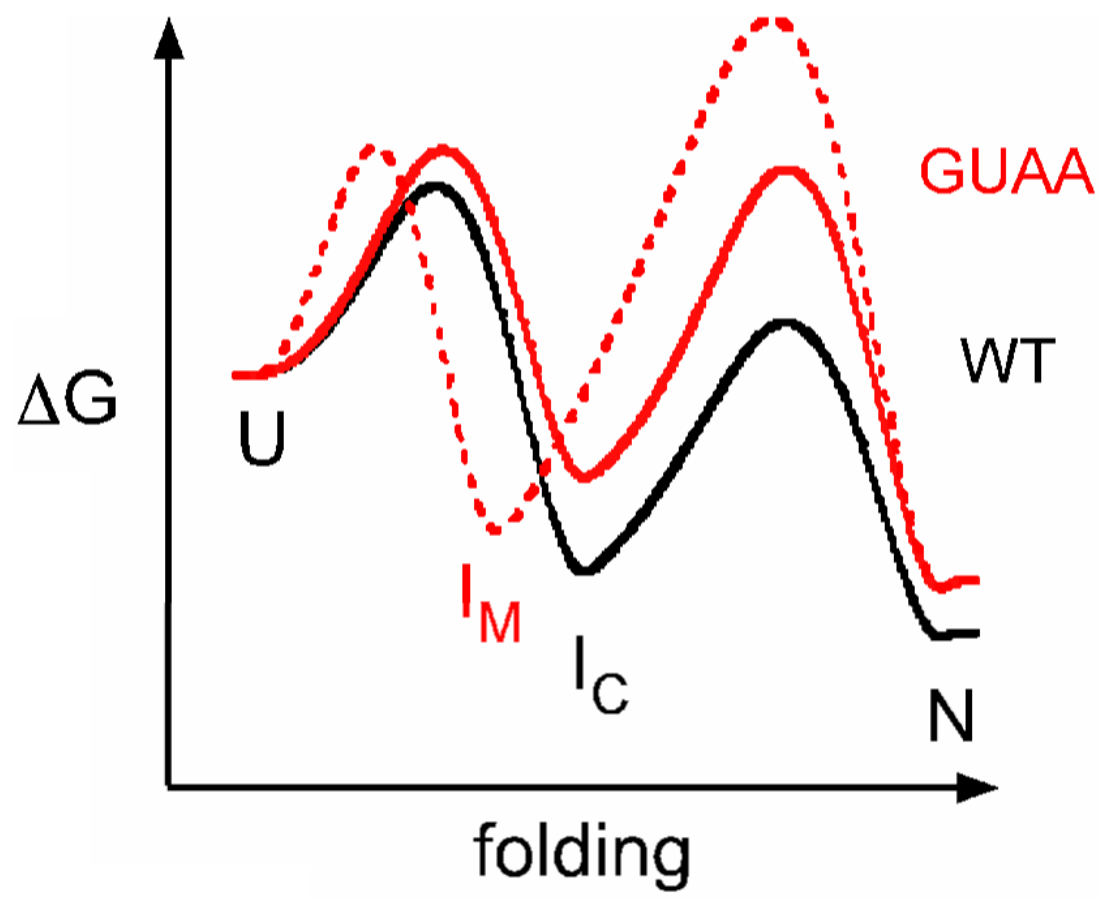

Figure 6. Free energy landscape for folding the Azoarcus ribozyme

The wild type ribozyme (black) folds to $\mathrm{N}$ with $\tau_{\square \text { व }} \sim 5 \mathrm{~ms}$ via the native-like intermediate $\mathrm{I}_{\mathrm{C}}$. The GUAA ribozyme (red) folds along at least two pathways, via $\mathrm{I}_{\mathrm{C}}$ or a metastable intermediate $\mathrm{I}_{\mathrm{M}}\left(\tau_{\square \mathrm{\square}} \sim 40 \mathrm{~ms}\right.$ and $\left.100 \mathrm{~s}\right)$. Free energies of $\mathrm{I}_{\mathrm{C}}$ and $\mathrm{N}$ relative to $\mathrm{U}$ were taken from the $\mathrm{Mg}^{2+}$-dependence of native PAGE $\left(\Delta \mathrm{G}_{\mathrm{UI}}\right)$ and ribozyme activity $\left(\Delta \mathrm{G}_{\mathrm{IN}}\right)$ at $50{ }^{\circ} \mathrm{C}$ in 1 and $5 \mathrm{mM} \mathrm{MgCl}_{2}$, respectively. ${ }^{14}$ The energy barriers were scaled in proportion to the folding times $\left(\tau_{\text {obs }}\right)$ at $37{ }^{\circ} \mathrm{C}$, assuming $\tau_{\text {obs }}=\tau_{0} \tau^{\ddagger}$ and $\tau_{0} \sim 1 \mu \mathrm{s}$. The relative energy barriers are expected to scale similarly between $37^{\circ}$ and $50{ }^{\circ} \mathrm{C}$. 

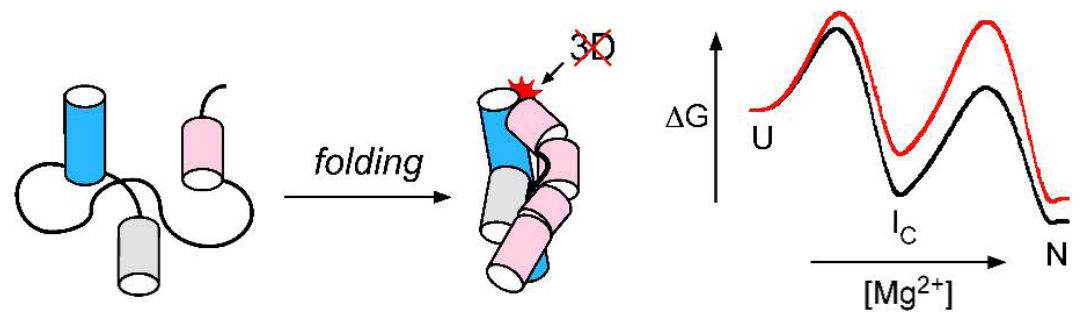

TOC Graphic. 


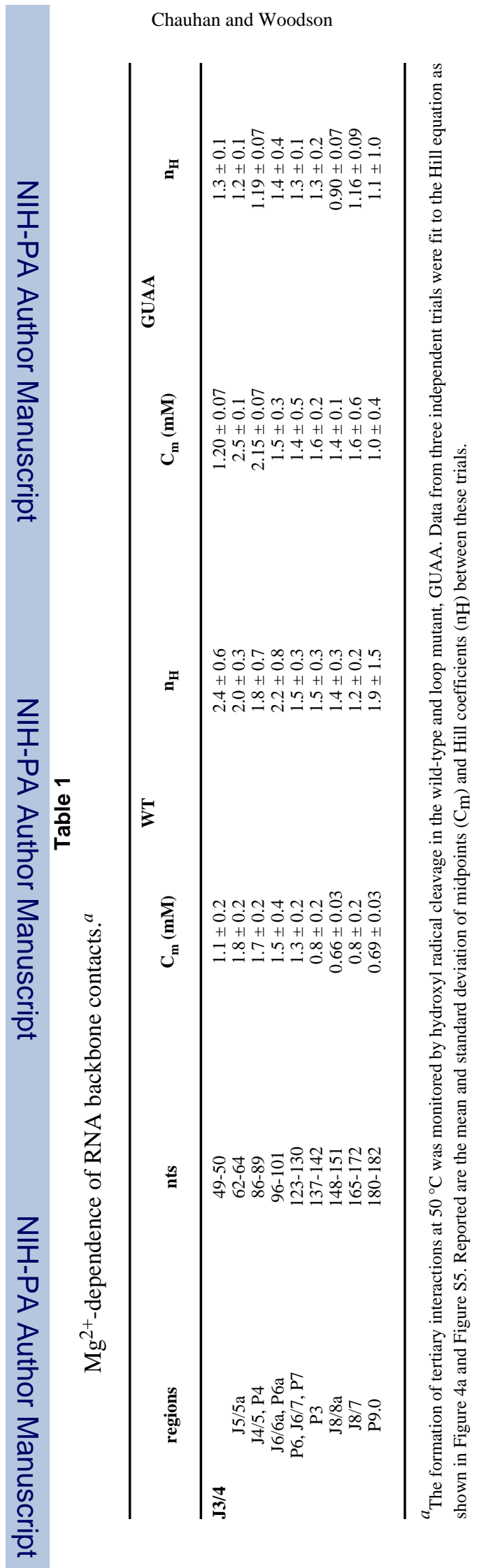

$J$ Am Chem Soc. Author manuscript; available in PMC 2009 January 30. 